Article

\title{
Sudden Changes in Water Hardness Do Not Impact Short-Term Rainbow Trout Survival
}

\author{
Nathan Huysman *, Jill M. Voorhees (D), Eric Krebs and Michael E. Barnes
}

check for updates

Citation: Huysman, N.; Voorhees, J.M.; Krebs, E.; Barnes, M.E. Sudden Changes in Water Hardness Do Not Impact Short-Term Rainbow Trout Survival. Fishes 2022, 7, 44. https:// doi.org/10.3390/fishes7010044

Academic Editors: José Lino Costa and Bernardo Baldisserotto

Received: 3 January 2022

Accepted: 9 February 2022

Published: 11 February 2022

Publisher's Note: MDPI stays neutral with regard to jurisdictional claims in published maps and institutional affiliations.

Copyright: (c) 2022 by the authors. Licensee MDPI, Basel, Switzerland. This article is an open access article distributed under the terms and conditions of the Creative Commons Attribution (CC BY) license (https:/ / creativecommons.org/licenses/by/ $4.0 /)$.
South Dakota Game, Fish \& Parks, McNenny State Fish Hatchery, 19619 Trout Loop, Spearfish, SD 57783, USA; jill.voorhees@state.sd.us (J.M.V.); eric.krebs@state.sd.us (E.K.); mike.barnes@state.sd.us (M.E.B.)

* Correspondence: nathan.huysman@state.sd.us; Tel.: +1-605-642-6920; Fax: +1-605-642-6921

\begin{abstract}
Fish transferred from hard water to soft water, as can occur during the stocking of hatcheryreared fish into natural environments, experience many physiological stressors that can cause mortality. This study consisted of four trials examining the effects of direct transfer from hard $\left(345 \mathrm{mg} / \mathrm{L} \mathrm{CaCO}_{3}\right)$ to soft water on mortality and glucose stress response of two different sizes and strains of rainbow trout Oncorhynchus mykiss. The first trial subjected $90 \mathrm{~g}$ Shasta strain rainbow trout to a direct transfer to soft water $\left(70\right.$ or $160 \mathrm{mg} / \mathrm{L}$ as $\left.\mathrm{CaCO}_{3}\right)$. The second trial used the same strain and size trout, with transfer to lower hardness values of either 0 or $35 \mathrm{mg} / \mathrm{L}$. The third and fourth trials used 3 to $5 \mathrm{~g}$ Arlee strain rainbow trout. The third trial transferred the fish from $345 \mathrm{mg} / \mathrm{L}$ hardness water to water at a hardness of either 0 or $35 \mathrm{mg} / \mathrm{L}$. The fourth trial added a secondary temperature stressor of $20^{\circ} \mathrm{C}$ (versus the experimental standard of $11^{\circ} \mathrm{C}$ ) in combination with a hardness level of $0 \mathrm{mg} / \mathrm{L}$. In every trial, survival was not significantly different among all treatments. Sudden and extreme changes in water hardness, even in combination with increased water temperature, did not cause trout mortality. There was also no significant difference in blood glucose over time among any of the treatments in the first three trials. In the fourth trial, glucose values did significantly vary among the treatments at 48 and $168 \mathrm{~h}$ after the start of the trial. However, all glucose values were relatively close to the basal level. These results indicate that changes in water hardness likely do not impact the survival of rainbow trout, negating the need for tempering or acclimation.
\end{abstract}

Keywords: hardness; water quality; tempering; rainbow trout; Oncorhynchus mykiss

\section{Introduction}

Fish reared in conservation and recreational hatcheries are frequently stocked into waters with different temperatures and chemical compositions. The effects of temperature changes on the survival of stocked fish have been widely studied [1-6]. Despite the consistent evidence that fish can readily tolerate temperature changes between thermal minimums and maximums, thermal tempering is still widely recommended [7-11].

Recently, changes in water hardness (as $\mathrm{CaCO}_{3}$ ) have been linked to the failure of selected sockeye salmon Oncorhynchus nerka stockings [12]. Trushenski et al. [12] reported that the sudden transition from hard to soft water affected salmon post-stocking survival. Fish reared in hard water and transferred to soft water experience many physiological stressors [13-18]. Dramatic changes in water hardness can cause morbidity [12,19] and mortality $[12,20,21]$.

Various methods have been proposed to mitigate the potentially negative effects of changes in water hardness. Release site tempering has been suggested but is no longer a viable option due to potential disease or aquatic invasive species transfer [22-24]. Acclimation has also been considered [12], but in-hatchery acclimation is very difficult for flow-through or pond systems. Recirculation hatcheries have greater potential for acclimation, but altering vast quantities of water would still require considerable resources and facility re-design. Ultimately, McDonald and Robinson [14] stated that fish to be stocked in soft water should be reared in a soft water hatchery. 
It must be noted that there have been no completely controlled experimental evaluations concerning the potential effects of just water hardness on the post-stocking survival of hatchery-reared fish. Thompson et al. [19] is the most controlled hardness study, but they examined hardness in relation to $\mathrm{pH}$. Data concerning the need for water hardness acclimation is greatly needed. In the US state of South Dakota alone, 77 different water bodies were stocked with salmonids reared in two hatcheries with very hard water [25]. Each of the waters stocked have different water hardness levels. Since hatchery-reared fish represent a considerable financial investment, it is imperative that they are stocked in a manner that best ensures their survival, as well as to avoid an increase in the risk of disease or aquatic invasive species transfer back to the hatchery itself [26]. Thus, the objective of this study was to examine the effects of a sudden change from hard water to different levels of soft water on the stress response and short-term survival of rainbow trout Oncorhynchus mykiss.

\section{Materials and Methods}

Four experiments were designed to test the stress response and survival of juvenile rainbow trout subjected to a dramatic shift in water hardness. Each trial was designed consecutively, with parameters in subsequent trials based on the results from the previous trial.

\subsection{Methods Common to Each Experiment}

All experiments were conducted with rainbow trout at McNenny State Fish Hatchery, Spearfish, South Dakota, USA. The trout used in all trials were hatched and reared in aerated and degassed well water $\left(11.2{ }^{\circ} \mathrm{C}\right.$; total hardness $345 \mathrm{mg} / \mathrm{L} \mathrm{CaCO}_{3}$; alkalinity as $\mathrm{CaCO}_{3} 210 \mathrm{mg} / \mathrm{L} ; \mathrm{pH}$ 8.3; total dissolved solids $460 \mathrm{mg} / \mathrm{L}$ ). Experimental units were $190 \mathrm{~L}$ (160 L working volume) semi-square tanks. Each tank was outfitted with a submersible recirculating pump (Pondmaster, Kissimmee, FL, USA) attached to a spray bar that maintained dissolved oxygen levels near saturation. Tank temperatures (when applicable) were controlled using a submersible heater (Hydor, Bassano del Grappa, Italy) attached to a temperature controller (Finnex, Chicago, IL, USA) which maintained desired temperatures at $\pm 1{ }^{\circ} \mathrm{C}$ over the course of the trial. Different water hardness levels were attained by mixing softened hatchery water (WaterRight Softener, Appleton, WI, USA) with unsoftened hatchery water. Water chemistry testing occurred both before and after mixing, with minimal variation observed in conductivity ( 645 to $665 \mu \mathrm{S}$ ), alkalinity ( 210 to $220 \mathrm{mg} / \mathrm{L} \mathrm{CaCO}_{3}$ ), $\mathrm{pH}$ (8.3), salinity (280-300 PSU), and total dissolved solids (TDU; 430-460 mg/L).

Tanks were monitored daily for total ammonia levels using a total ammonia test kit (LaMotte, Chestertown, MD, USA), with ammonia levels maintained below $0.50 \mathrm{mg} / \mathrm{L}$ (free ammonia) using an ammonia detoxifier (AmQuel, Kordon, Hayward, CA, USA). At the start of each trial, each tank received five fish from a common tank. Fish were not fed the day before or during each 14-day trial. The trial duration was selected because $70 \%$ of the trout stocked in South Dakota are assumed to be caught within 14 days post-stocking [27]. At $4,6,48,120$, and $336 \mathrm{~h}$ after the start of the trial, one fish from each tank was euthanized with a lethal dose of tricaine methane sulfonate (MS-222, Syndel, Ferndale, WA, USA) and blood glucose was measured (Accu-Chek Aviva Plus, Roche Diabetic Care, Indianapolis, IN, USA). Basal levels of glucose were taken from the common pool of fish before transfer using the same protocol. Fish were weighed to the nearest $g$ and measured (total length) to the nearest $\mathrm{mm}$ at the end of the trial or when mortality occurred.

\subsection{Trials}

Trial 1 used Shasta strain juvenile rainbow trout (mean \pm SD, total length $203 \pm 14 \mathrm{~mm}$, weight $90.7 \pm 17.2 \mathrm{~g}$ ). The fish were netted from a common pool with a water hardness of $345 \mathrm{mg} / \mathrm{L}$ and immediately placed into three different water hardness levels (70, 160, and $345 \mathrm{mg} / \mathrm{L} ; n=4)$. Based on the results of the first trial, lower water hardness values $(0,35$, and $345 \mathrm{mg} / \mathrm{L})$ were used in the second trial with the same strain of rainbow trout. 
The final two trials used smaller juvenile Arlee strain rainbow trout. The third trial used the same water hardness levels as the second trial $(0,35$, and $345 \mathrm{mg} / \mathrm{L})$, but trout mean total lengths were only $66 \pm 6 \mathrm{~mm}$ and mean weights were only $2.9 \pm 0.9 \mathrm{~g}$. The fourth and final trial used a two-way factorial design $(n=3)$ with two temperatures $\left(11^{\circ} \mathrm{C}\right.$ and $\left.20^{\circ} \mathrm{C}\right)$ and two hardness levels $(0$ and $345 \mathrm{mg} / \mathrm{L})$. Increasing water temperature from $11^{\circ} \mathrm{C}$ to $20^{\circ} \mathrm{C}$ was chosen as this temperature change has been shown to be stressful but not deadly $[3,6]$, thereby introducing a sub-lethal stressor in addition to the change in water hardness. Table 1 provides an overview of the experimental design for each trial.

Table 1. Experimental design for each of the trials conducted in this study. Trial 1 and 2 used Shasta strain juvenile rainbow trout Oncorhynchus mykiss (mean \pm SD, total length $203 \pm 14 \mathrm{~mm}$, weight $90.7 \pm 17.2 \mathrm{~g}, n=4$ ). Trial 3 and 4 used Arlee strain juvenile rainbow trout (mean $\pm \mathrm{SD}$, total length $66 \pm 6 \mathrm{~mm}$, weight $2.9 \pm 0.9 \mathrm{~g}, n=4)$. All fish were directly transferred from a common pool at $11^{\circ} \mathrm{C}$ and hardness of $345 \mathrm{mg} / \mathrm{L} \mathrm{CaCO}_{3}$.

\begin{tabular}{|c|c|c|}
\hline Trial & Hardness (mg/L CaCO 3$)$ & Temperature $\left({ }^{\circ} \mathrm{C}\right)$ \\
\hline \multirow{3}{*}{1} & 70 & 11 \\
\hline & 160 & 11 \\
\hline & 345 & 11 \\
\hline \multirow{3}{*}{2} & 0 & 11 \\
\hline & 35 & 11 \\
\hline & 345 & 11 \\
\hline \multirow{3}{*}{3} & 0 & 11 \\
\hline & 35 & 11 \\
\hline & 345 & 11 \\
\hline \multirow{4}{*}{4} & 0 & 11 \\
\hline & 0 & 20 \\
\hline & 345 & 11 \\
\hline & 345 & 20 \\
\hline
\end{tabular}

\subsection{Statistical Analysis}

Following the experiments, a chi-square analysis (SPSS 24.0; IBM, Armonk, NY, USA) was performed on each separate experiment to determine if there were any differences in survival between treatments. A repeated measures ANOVA with Greenhouse-Geisser correction was used to determine if there were any differences in glucose levels over time between treatments for each experiment. If a difference did occur, then a one-way ANOVA with a Tukey's means comparison post-hoc test was performed at each timepoint. A twoway ANOVA with water temperature and hardness as the variables was performed for experiment 4 for glucose levels at each timepoint. Significance was pre-determined at $p<0.05$.

\section{Results}

In every trial, survival was not significantly different among all treatments (Table 2). Only two total fish died in all four trials; a control $(345 \mathrm{mg} / \mathrm{L})$ fish died on day 10 in the second trial, and a $35 \mathrm{mg} / \mathrm{L}$ treatment fish died on day 2 in the third trial. There was also no significant difference in glucose over time among any of the treatments in the first three trials (Figures 1-3; $p=0.34,0.54$, and 0.77 for trials 1, 2, and 3, respectively). 
Table 2. Percent survival, number of days alive, and chi-square $p$-value for each of four trials testing 14-day survival of rainbow trout Oncorhynchus mykiss $(n=4)$ exposed to different water hardness levels.

\begin{tabular}{|c|c|c|c|}
\hline Trial & Survival (\%) & Days Alive & $p$-Value \\
\hline \multirow{3}{*}{1} & 100 & 14 & \multirow{3}{*}{$\mathrm{N} / \mathrm{A}$} \\
\hline & 100 & 14 & \\
\hline & 100 & 14 & \\
\hline \multirow{3}{*}{2} & 100 & 14 & \multirow{3}{*}{0.34} \\
\hline & 100 & 14 & \\
\hline & 75 & $13 \pm 1$ & \\
\hline \multirow{3}{*}{3} & 100 & 14 & \multirow{3}{*}{0.34} \\
\hline & 75 & $11 \pm 3$ & \\
\hline & 100 & 14 & \\
\hline \multirow{4}{*}{4} & 100 & 14 & \multirow{4}{*}{$\mathrm{N} / \mathrm{A}$} \\
\hline & 100 & 14 & \\
\hline & 100 & 14 & \\
\hline & 100 & 14 & \\
\hline
\end{tabular}

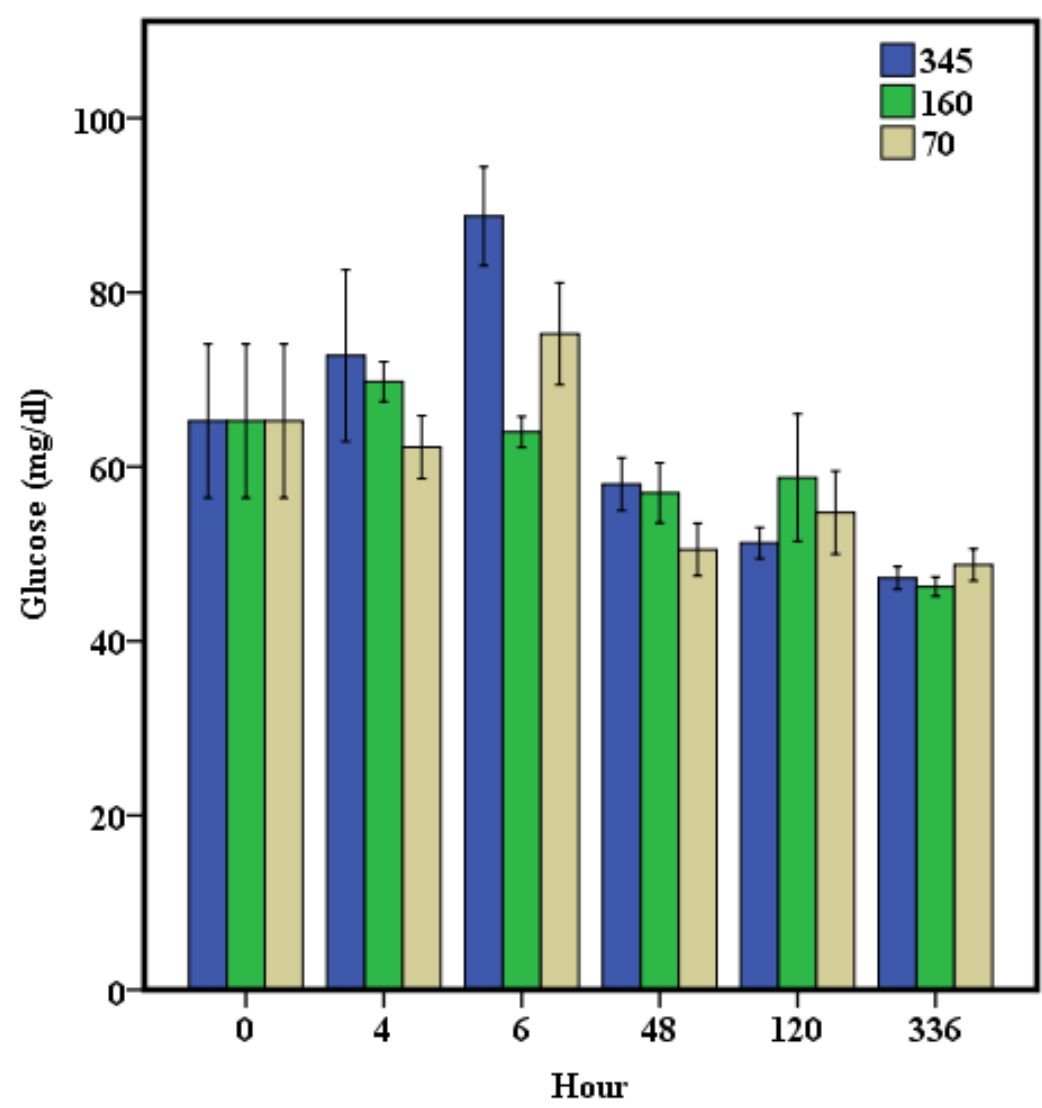

Figure 1. Trial 1 glucose levels $( \pm \mathrm{SE}$ ) at the beginning (hour 0-before transfer, hardness of $345 \mathrm{mg} / \mathrm{L}$ ) and $4,6,48,120$, and 336 hours after the start of the trial when rainbow trout Oncorhynchus mykiss ( $n=4$ for each treatment at each timepoint) were directly transferred from $345 \mathrm{mg} / \mathrm{L}$ water hardness to experimental conditions without acclimation. 


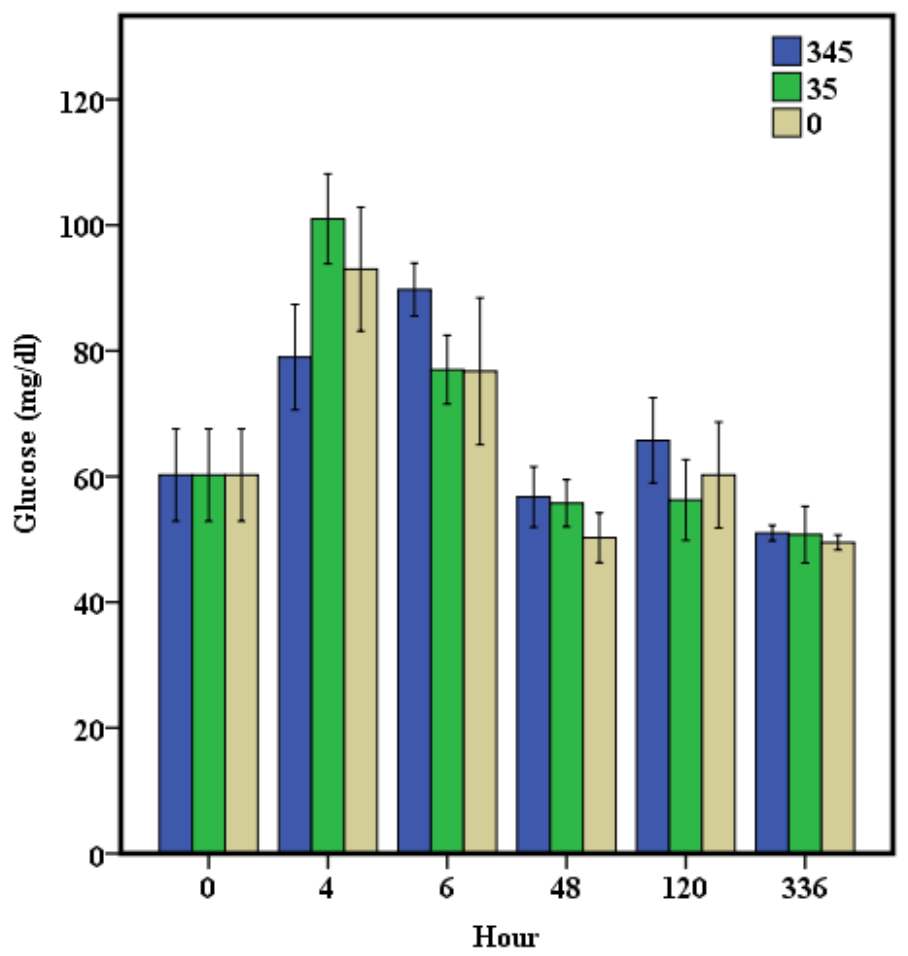

Figure 2. Trial 2 glucose levels ( $\pm \mathrm{SE}$ ) at the beginning (hour 0 -before transfer, hardness of $345 \mathrm{mg} / \mathrm{L}$ ) and $4,6,48,120$, and 336 hours after the start of the trial when rainbow trout Oncorhynchus mykiss ( $n=4$ for each treatment at each timepoint) were directly transferred from $345 \mathrm{mg} / \mathrm{L}$ water hardness to experimental conditions without acclimation.

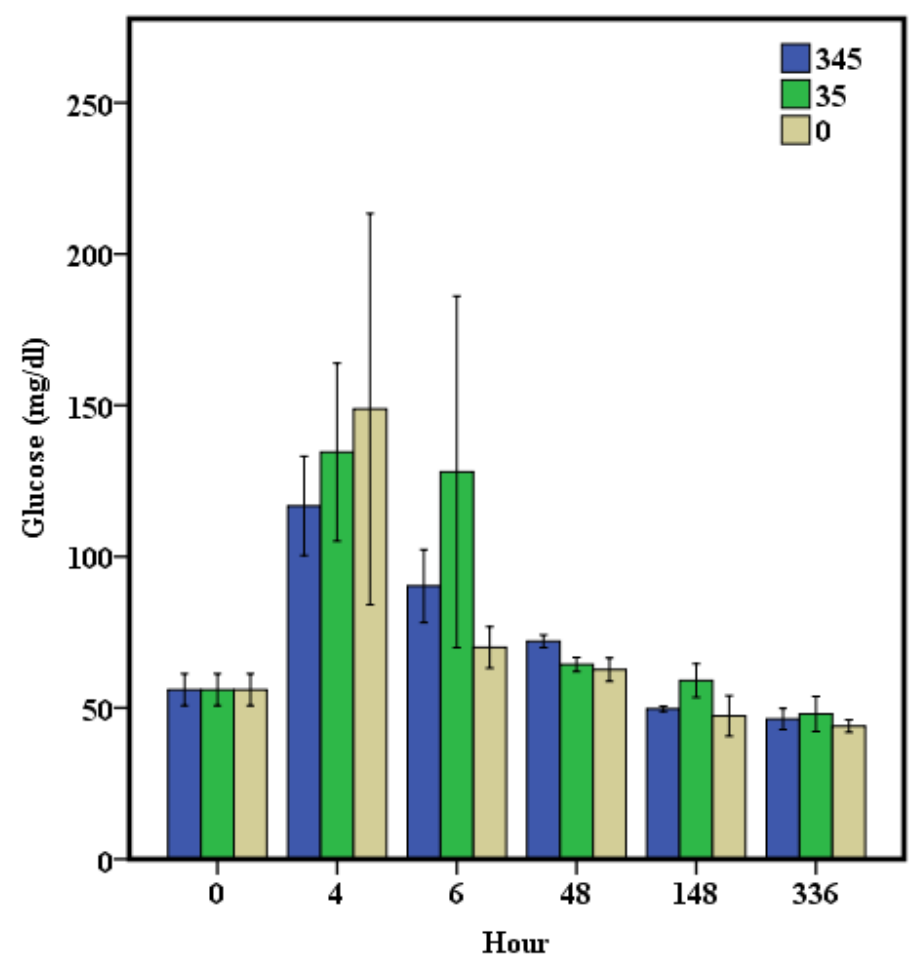

Figure 3. Trial 3 glucose levels $( \pm \mathrm{SE}$ ) at the beginning (hour 0-before transfer, basal hardness of $345 \mathrm{mg} / \mathrm{L}$ ) and 4, 6, 48,120, and 336 hours after the start of the trial when rainbow trout Oncorhynchus mykiss ( $n=4$ for each treatment at each timepoint) were directly transferred from $345 \mathrm{mg} / \mathrm{L}$ water hardness to experimental conditions without acclimation. 
With blood glucose in the fourth trial, there was a significant interaction between hardness and temperature for hour $48(p=0.046)$ and hour $168(p=0.008)$ (Figure 4$)$. Subsequent analysis using a one-way ANOVA indicated a significant difference in blood glucose at hour 48 between the fish at $0 \mathrm{mg} / \mathrm{L}$ hardness and $11^{\circ} \mathrm{C}(65.75 \mathrm{mg} / \mathrm{dL})$ and fish at $345 \mathrm{mg} / \mathrm{L}$ and $20^{\circ} \mathrm{C}(53.25 \mathrm{mg} / \mathrm{dL})$. Similarly, on hour 168 , glucose was significantly different between the fish in the $0 \mathrm{mg} / \mathrm{L}$ hardness and $20^{\circ} \mathrm{C}$ treatment $(48.75 \mathrm{mg} / \mathrm{dL})$ compared to the fish in the $345 \mathrm{mg} / \mathrm{L}$ hardness and $20^{\circ} \mathrm{C}$ treatment $(58.25 \mathrm{mg} / \mathrm{dL})$. However, all glucose values were relatively close to the basal level of $57.75 \mathrm{mg} / \mathrm{dL}$. By the end of the trial (14-days), all glucose values were below basal.

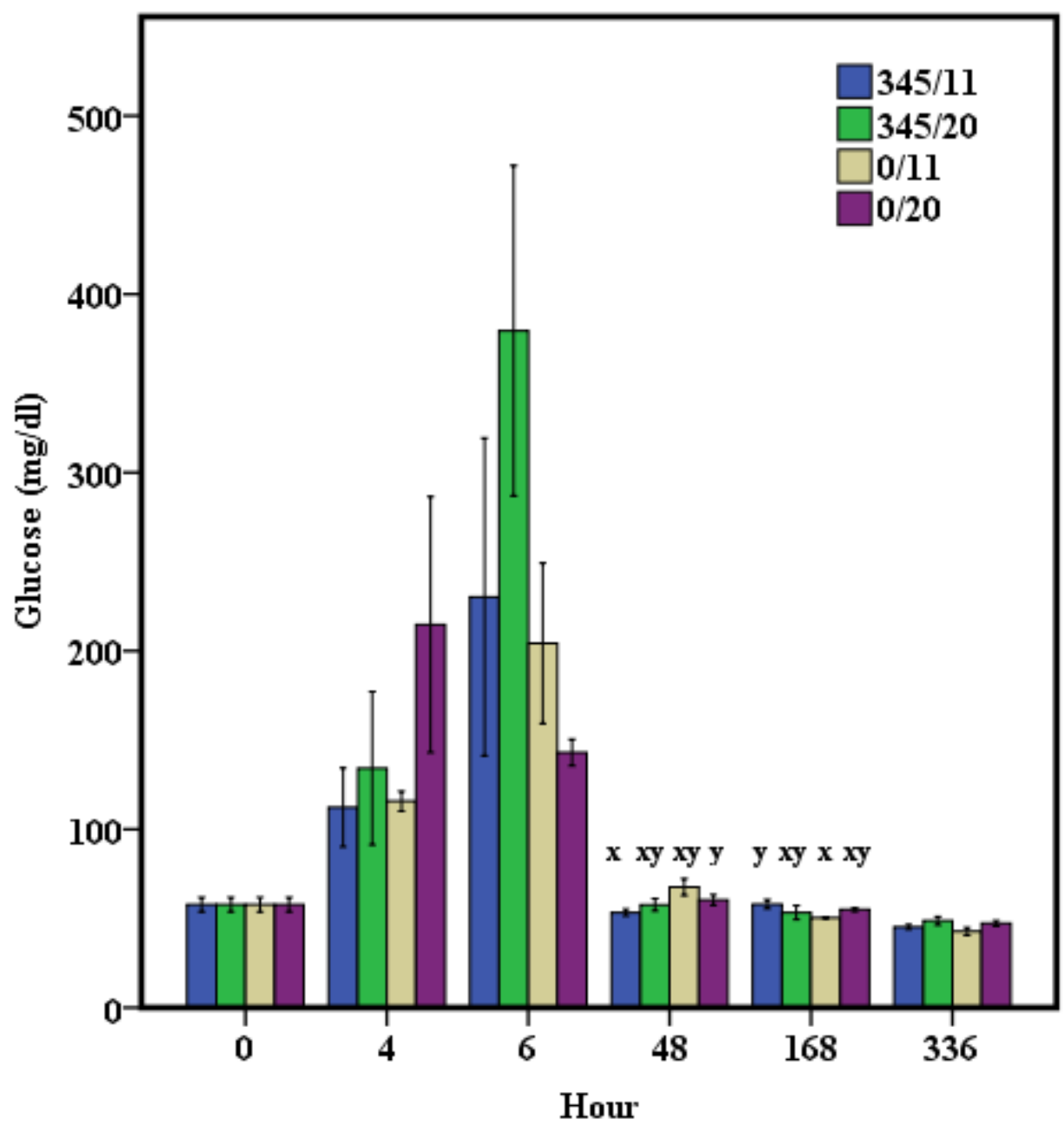

Figure 4. Trial 4 glucose levels $( \pm \mathrm{SE})$ at the beginning (hour 0-before transfer, basal hardness of $345 \mathrm{mg} / \mathrm{L}$ and $11^{\circ} \mathrm{C}$ ) and $4,6,48,168$, and 336 hours after the start of the trial when rainbow trout Oncorhynchus mykiss ( $n=4$ for each treatment at each timepoint) were directly transferred from $345 \mathrm{mg} / \mathrm{L}$ water hardness and $11^{\circ} \mathrm{C}$ to experimental conditions without acclimation. For a given timepoint, means with a different letter are significantly different $(p<0.05)$.

\section{Discussion}

The lack of mortality due to extreme, sudden changes in water hardness was unexpected, especially when a second stressor (temperature) was added. Previous studies observed considerable stress and mortality due to changes in water hardness and water chemistry $[12,14,21,28]$. Furthermore, many recommend acclimation or tempering prestocking $[1,5,7,12,29]$. While increased glucose levels indicated a stress response due to the change, the lack of mortality clearly indicates that rainbow trout can survive extreme and rapid changes from hard to soft water. 
Stocking programs where fish are reared in hard water and stocked in softer receiving waters are relatively common $[12,14,19,30]$. Even with the extreme changes used in this study, there were no significant differences in mortality in two different strains and sizes of rainbow trout. Stress responses were similar for all treatments and returned to near basal levels within approximately $48 \mathrm{~h}$ indicating a strong stress response to handling and transfer, along with relatively rapid acclimation to new conditions.

Many physiological changes occur when a fish is transferred from hard to soft water. Due to altered ionic balances, gill filament and lamellar chloride cells increase to assist with ion transfer [31-33]. Hyperventilation also occurs to counteract the thickening of the gill diffusion barrier $[15,17]$. The lack of mortality in the current study indicate that the strains and sizes of rainbow trout used were able withstand these physiological challenges, at least for the 14 days.

This study was conducted in a controlled environment. Fish were not subjected to the natural stressors of being released to a new environment and did not have to avoid predation, forage, or look for suitable habitat. Trushenski et al. [12] observed very poor survival with sockeye salmon smolts transferred from a hard water hatchery environment to a soft water natural environment without acclimation. It is unknown if survival would have been different in our fish if they were subjected to the stress of a natural water body.

The two different strains of trout used in this study yielded similar results. Both the Shasta and Arlee strains are highly domesticated, and the Shasta strain may have low longterm survival in natural ecosystems [34-36]. More wild strains may survive and reproduce better when stocked into natural waters [37]. It is unknown if a less-domesticated strain of rainbow trout would effectively survive the water hardness change of this study. The performance of other fish species is also unknown.

The current study controlled for water hardness; other water chemistry quality parameters were unchanged. In natural waters, changes in water hardness typically occur with other changes, such as alkalinity. Extreme changes in alkalinity can be very stressful to fish [38,39]. Although focused on water hardness, Trushenski et al. [12] also noted extreme changes in alkalinity from the different receiving and hatchery waters that were not considered. Simply reducing hardness does not necessarily reduce alkalinity levels while tempering [40]. Alkalinity levels in the water can alter and affect fish blood acid-base status and gas exchange [38,39]. High levels of alkalinity likely also improves resistance to copper toxicity in fish [41]. It is possible that by maintaining high alkalinity levels in conjunction with reducing water hardness, the trout in the current experiment were better able to withstand the drastic change in hardness.

The results of this study indicate that tempering for water hardness is not needed when fish are transferred from high to low hardness waters. Reducing the need for water transfer during tempering reduces the risk of fish pathogen and aquatic invasive species transmission [5,22-24]. In addition, with respect to water hardness, tempering is far less beneficial compared to acclimation $[12,42,43]$.

This study was limited by a relatively small sample size. Unfortunately, system and facility limitations prevented a larger scale design. It would be beneficial to test survival on larger sample sizes of fish and for longer time periods. This study was also limited in that it did not mimic the natural temperature variations that can occur in the wild. Fish may have been able to acclimate to the $20{ }^{\circ} \mathrm{C}$ stressor that was applied to them. Further experimentation mimicking natural, and possibly more extreme, temperature fluctuation would be beneficial to determine how that additional stressor would affect survival with extreme changes in water hardness.

In conclusion, the two domesticated strains and sizes of rainbow trout used in this study were able to survive up to 14-days after transfer from water hardness levels of 345 to $0 \mathrm{mg} / \mathrm{L} \mathrm{CaCO}_{3}$, even when an additional temperature stressor was applied. Future studies should further examine the potential effects on fish survival with extreme changes in alkalinity and other water chemistry components related to water hardness. Controlled experimentation isolating the potential impacts on fish survival of the stressors present 
in natural environments in conjunction with changes in water hardness would also be beneficial. Lastly, the effects of immediate and extreme water hardness changes on larger sizes of trout, as well as other fish species, should be determined.

Author Contributions: Conceptualization, N.H, J.M.V., E.K. and M.E.B.; methodology, N.H. and E.K.; formal analysis, N.H.; investigation, N.H.; data curation, N.H, J.M.V. and E.K.; writing-original draft preparation, N.H.; writing - review and editing, N.H, J.M.V., E.K. and M.E.B.; All authors have read and agreed to the published version of the manuscript.

Funding: This research received no external funding.

Institutional Review Board Statement: This experiment was performed within the guidelines set out by the Aquatics Section Research Ethics Committee of the South Dakota Department of Game, Fish and Parks (approval code, SDGFPARC20211), and within the guidelines for the Use of Fishes in Research set by the American Fisheries Society.

Data Availability Statement: Data available upon request from authors.

Acknowledgments: We thank Ashley Kelican and Michael Robideaux for their assistance with this study.

Conflicts of Interest: The authors declare no conflict of interest.

\section{References}

1. Brett, J.R. Tempering versus acclimation in the planting of speckled trout. Trans. Am. Fish. Soc. 1941, 70, 397-403. [CrossRef]

2. Mather, M.E.; Wahl, D.H. Comparative mortality of three escoids due to stocking stressors. Can. J. Fish. Aquat. Sci. 1989, 46, 214-217. [CrossRef]

3. Wedemeyer, G.A. Physiology of Intensive Culture Systems; Chapman and Hall: New York, NY, USA, 1996.

4. Clapp, D.F.; Bhagwat, Y.; Wahl, D.H. The effect of thermal stress on walleye fry and fingerling mortality. N. Am. J. Fish. Manag. 1997, 17, 429-437. [CrossRef]

5. Smith, M.A.; Hubert, W.A. Simulated thermal tempering versus sudden temperature change and short-term survival of fingerling rainbow trout. N. Am. J. Aquac. 2003, 65, 67-69. [CrossRef]

6. Huysman, N.; Voorhees, J.M.; Krebs, E.; Barnes, M.E. Thermal tempering does not impact rainbow and brown trout survival. Adv. Biosci. Biotechnol. 2020, 11, 345-353. [CrossRef]

7. $\quad$ Piper, R.G.; McElwain, I.B.; Orme, L.E.; McCraren, J.P.; Fowler, L.G.; Leonard, J.R. Fish Hatchery Management; U.S. Fish and Wildlife Service: Washington, DC, USA, 1982.

8. Noga, E.J. Fish Disease: Diagnosis and Treatment; Iowa State University Press: Ames, IA, USA, 2000.

9. Timmons, E.B.; Ebeling, J.B.; Wheaton, F.W.; Summerfelt, S.T.; Cayuga, B.J. Recirculating Aquaculture Systems; Cayuga Aqua Adventures: Ithaca, NY, USA, 2002; No. SH137. R37.

10. Harmon, T.S. Methods for reducing stressors and maintaining water quality associated with live fish transport in tanks: A review of the basics. Rev. Aquac. 2009, 1, 58-66. [CrossRef]

11. Wynne, F.; Wurts, W.A. Transportation of Warmwater Fish: Equipment and Guidelines; Southern Regional Aquaculture Center: Stoneville, MS, USA, 2011.

12. Trushenski, J.T.; Larsen, D.A.; Middleton, M.A.; Jakaitis, M.; Johnson, E.L.; Kozfkay, C.C.; Kline, P.A. Search for the smoking gun: Identifying and addressing the causes of postrelease morbidity and mortality of hatchery-reared Snake River sockeye salmon smolts. Trans. Am. Fish. Soc. 2019, 145, 875-895. [CrossRef]

13. McDonald, D.G.; Rogano, M.S. Ion regulation by the Rainbow Trout, Salmo gairdneri, in ion-poor water. Physiol. Zool. 1986, 59, 318-331. [CrossRef]

14. McDonald, D.G.; Robinson, J.G. Physiological responses of Lake Trout to stress: Effects of water hardness and genotype. Trans. Am. Fish. Soc. 1993, 122, 1146-1155. [CrossRef]

15. Greco, A.M.; Gilmour, K.M.; Fenwick, J.C.; Perry, S.F. The effects of softwater acclimation on respiratory gas transfer in the rainbow trout Oncorhynchus mykiss. J. Exp. Biol. 1995, 198, 2557-2567. [CrossRef]

16. Laurent, P.; Dunel-Erb, S.; Chevalier, C.; Lignon, J. Gill epithelial cell kinetics in a freshwater teleost, Oncorhynchus mykiss, during adaptation to ion-poor water and hormonal treatments. Fish Physiol. Biochem. 1995, 13, 353-370. [CrossRef] [PubMed]

17. Perry, S.F.; Reid, S.G.; Wankiewicz, E.; Iyer, V.; Gilmour, K.M. Physiological responses of rainbow trout (Oncorhynchus mykiss) to prolonged exposure to soft water. Physiol. Zool. 1996, 69, 1419-1441. [CrossRef]

18. Sampaio, F.D.F.; Freire, C.A. An overview of stress physiology of fish transport: Changes in water quality as a function of transport duration. Fish Fish. 2016, 17, 1055-1072. [CrossRef]

19. Thompson, W.A.; Rodela, T.M.; Richards, J.G. Hardness does not affect the physiological responses of wild and domestic strains of diploid and triploid rainbow trout Oncorhynchus mykiss to short-term exposure to pH 9.5. J. Fish Biol. 2016, 89, 1345-1358. [CrossRef] [PubMed] 
20. Phillips, A.M. The known and possible role of minerals in trout nutrition and physiology. Trans. Am. Fish. Soc. 1959, 88, 133-135. [CrossRef]

21. Barton, B.A. Stress in fishes: A diversity of responses with particular reference to changes in circulating corticosteroids. Soc. Integr. Comp. Biol. 2002, 42, 517-525. [CrossRef]

22. Hnath, J.G. Hatchery disinfection and disposal of infected stocks. In A Guide to Integrated Fish Health Management in the Great Lakes Basin; Meyer, F.P., Warren, J.W., Carey, T.G., Eds.; Spec. Pub.: Ann Arbor, MI, USA, 1983; pp. 121-134.

23. Edwards, W.J.; Babcock-Johnson, L.; Culver, D.A. Field testing of protocols to prevent the spread of Zebra Mussels (Dreissena polymorpha) during fish hatchery and aquaculture activities. N. Am. J. Aquac. 2002, 64, 220-223. [CrossRef]

24. Pucherelli, S.F.; Portz, D.E.; Bloom, K.; Carmon, J.; Brenimer, S.; Hosler, D. Quagga mussel contamination of fish haul trucks by fish and development of effective potassium chloride and formalin treatments. J. Appl. Aquac. 2014, 26, 132-148. [CrossRef]

25. SDGFP (South Dakota Department of Game, Fish \& Parks). 2019 Annual Technical Fish Stocking Report; Pierre, SD, USA, 2019. Available online: https:/ /apps.sd.gov /GF56FisheriesReports (accessed on 14 December 2021).

26. SDGFP (South Dakota Department of Game, Fish \& Parks). Strategic Plan 2016-2020; Pierre, SD, USA, 2015. Available online: https:/ / gfp.sd.gov/userdocs/docs/strategic-plan-2.pdf (accessed on 14 December 2021).

27. Kientz, J.L.; Barnes, M.E.; Durben, D.J. Concentration of stocked rainbow trout catch and harvest by a small number of recreational anglers. J. Fish. Sci. Com 2017, 11, 67-76. [CrossRef]

28. Harper, C.; Wolf, J.C. Morphologic effects of the stress response in fish. ILAR J. 2009, 50, 387-396. [CrossRef]

29. Hartman, K.J.; Preston, B. Stocking. In Fish Hatchery Management, 2nd ed.; Wedemeyer, G.A., Ed.; American Fisheries Society: Bethesda, MD, USA, 2001; pp. 661-686.

30. Mazik, P.M.; Simco, B.A.; Parker, N.C. Influence of water hardness and salts on survival and physiological characteristics of striped bass during and after transport. Trans. Am. Fish. Soc. 1991, 120, 121-126. [CrossRef]

31. Perry, S.F.; Goss, G.G.; Fenwick, J.C. Interrelationships between gill chloride cell morphology and calcium uptake in freshwater teleosts. Fish Physiol. Biochem. 1992, 10, 327-337. [CrossRef] [PubMed]

32. Perry, S.F.; Goss, G.G.; Laurent, P.L. The interrelationships between gill chloride cell morphology and ionic uptake in four freshwater teleosts. Can. J. Zool. 1992, 70, 1775-1786. [CrossRef]

33. Perry, S.F.; Laurent, P.L. Environmental effects on fish gill structure and function. In Fish Ecophysiology; Rankin, J.C., Jensen, F.B., Eds.; Chapman Hall: London, UK, 1993; pp. 231-264. [CrossRef]

34. Needham, P.R.; Behnke, R.J. The origin of hatchery rainbow trout. Progress. Fish-Cult. 1962, 24, 156-158. [CrossRef]

35. Vincent, E.R. Effects of stocking catchable-size hatchery rainbow trout on two wild trout species in the Madison River and O'Dell Creek, Montana. N. Am. J. Fish. Manag. 1987, 7, 91-105. [CrossRef]

36. Barnes, M.E.; Simpson, G.; Durben, D.J. Post-stocking harvest of catchable-sized rainbow trout enhanced by dietary supplementation with a fully fermented commercial yeast culture during hatchery rearing. N. Am. J. Fish. Manag. 2009, 29, 1287-1295. [CrossRef]

37. Davis, J.L.; Wilhite, J.W.; Simpson, G.; Barnes, M.E.; Bertrand, K.N.; Willis, D.W. Contributions of stocked and naturally reproduced rainbow trout in Deerfield Reservoir System. Prairie Nat. 2013, 45, 46-56.

38. Thomas, S.; Poupin, J. A study of the effects of water carbonate alkalinity on some parameters of blood acid-base status in rainbow trout (Salmo gairdneri R.). J. Comp. Physiol. B 1985, 156, 29-34. [CrossRef]

39. Truchot, J.P.; Forgue, J. Effect of water alkalinity on gill $\mathrm{CO}_{2}$ exchange and internal $\mathrm{Pco}_{2}$ in aquatic animals. Comp. Biochem. Phys. A 1998, 119, 131-136. [CrossRef]

40. Boyd, C.E.; Tucker, C.S.; Somridhivej, B. Alkalinity and hardness: Critical but elusive concepts in aquaculture. J. World Aquac. Soc. 2016, 47, 6-41. [CrossRef]

41. Wurts, W.A.; Perschbacher, P.W. Effects of bicarbonate alkalinity and calcium on the acute toxicity of copper to juvenile channel catfish (Ictalurus punctatus). Aquaculture 1994, 125, 73-79. [CrossRef]

42. Wagner, E.J.; Bosakowski, T.; Interlmann, S. Combined effects of temperature and high $\mathrm{pH}$ on mortality and the stress response of rainbow trout after stocking. Trans. Am. Fish. Soc. 1997, 126, 985-998. [CrossRef]

43. Walker, H.D.; Coates, G.I.; Wilhelm, S. Impacts of increased tempering lengths on twenty-four-hour survival of hybrid striped bass fry. N. Am. J. Aquac. 2000, 62, 316-318. [CrossRef] 